\title{
Imperative of Leadership Education in Africa's Quest for Global Development Space
}

\author{
Adekunle Osidipe \\ China Africa Education Cooperation Research Center, Institute of African Studies, Zhejiang Normal University, \\ 688, Yingbin Avenue, Jinhua, Zhejiang Province, China 321004
}

\begin{abstract}
More than half a century after independence from the colonial powers, the spate of development in Africa remains a sharp contrast to the great expectations of the freedom struggle which led to the emergence of modern African countries. The continent is today occupying the lowest rung on the global development ladder beleaguered with widespread poverty, poverty-triggered violence, civil crisis, youth restiveness due to chronic unemployment, multi-facetted insecurity and many more constraints to stable development which have resulted in continuous massive emigration of majority of the working age population from the continent to other climes in search of greener pastures. The struggle of the continent to occupy a significant position in the global development space continues to remain elusive due to weak or non-existing institutional frameworks to provide the critical impetus and environment conducive for development. Several researches have placed the blame for these on the doorsteps of bad leadership and lack of good governance in Africa. Leadership at the public level is expected to proffer solutions to problems and challenges arising from their immediate environment's need to respond to changing circumstances within and outside. The challenge in most African countries over the years has been the paucity of leaders with the capacity to promote the requisite development for the continent to effectively occupy a significant space in global development commensurate with the enormous human and material resources the continent is endowed with. Using the eclectic method of inquiry, descriptive and historical overview of relevant themes, this paper explores the challenge of leadership and the attendant consequences. The quality of leadership in many African countries significantly impacts the rate of development or underdevelopment in these countries; the quality of leadership on the continent has adversely affected diverse sectors; especially, the education sector and the leadership in most African countries lacks the requisite capacity to promote the adaptation that will not only restore, but also promote the fundamental interests and values of their society when existing circumstances create contradiction between how things are being done and how they should be done. The study argues that there should be a thorough review of the education system in African countries to give room for leadership nurturing in students through a multi-phase leadership education that is multidisciplinary, global, and ethics oriented as panacea for many of the leadership challenges in many African countries. The inclusion of leadership education in school curriculum will engender the preparation of students with practical and requisite skills that will enhance their ability to be effective leaders in future whether in public or private sector, overcoming the disaster of leadership of the current dispensation while giving assurance for a better future for the continent and the world at large.
\end{abstract}

Keywords: Africa; Leadership; Development; Education

DOI: $10.7176 / \mathrm{DCS} / 9-6-07$

Publication date: June $30^{\text {th }} 2019$

\section{Introduction}

With more than half a century of independence, many countries on the continent of Africa are still in a state that is direct opposite to the expectations of the freedom "fighters' under the colonial governments. The leadership in these countries have been largely blamed for the chronic developmental crises politically, socially and economically that has confined many people on the continent to abject poverty, struggling to survive in working poverty, unending violence, persistent food crisis. These crises are reflections of the failure of public leadership in Africa since independence with some leaders who took the reign of leadership from colonialists maintaining aspects of colonial state in the post-colonial states which inevitably nurtured civic and civil conflicts that sabotaged the opportunities for creative leadership and growth on the continent (Jallow, 2014). It is worth noting here that Africa has her share of good leaders who have contributed to the development of their various countries at one point or the other, but the review of the activities of these few are not within the scope of this paper. Also worthy of note is that the good leaders often got their tenure truncated or they got fatally eliminated by forces within or outside their countries, thereby plunging the countries back to the alleys of underdevelopment.

On the economic front, leadership failure is at the root of consistent entrapment of Africa countries under heavy external debt burden, commodity price fluctuations with attendant adverse consequences since the economies of most of the countries on the continent run on resource-export proceeds. The economic woes of the continent are preponderantly linked to the over-dependence of the African countries on borrowed policies and systems from the former colonial powers (Gumede, 2015; Watson, 1994) which translated into a vicious 
voluntary entrapment that has kept them perpetually underdeveloped in the midst of the abundant natural and human resources the continent is endowed with. The dismal economic performance on the continent has been described as the most challenging puzzles of growth theory with the growth rate of per-capita income of African countries standing below world average for more than half a century (Bertocchi \& Canova, 2002).

The failure of leadership on the continent engendered and escalated prevalent poverty, infrastructural underdevelopment, misappropriation of public funds embezzlement and inability to maximize the continent's demographic dividend by creating enabling environment to effectively maximize the potential and value of the bourgeoning working age population among others (Folarin, 2013; Izugbara, Tilahun, \& Owii, 2018). The lack of quality leadership in the helm of affairs in the African nations inadvertently pushed the continent to the brink of cyclic crisis occasioned by poorly implemented restructuring programmes and wrongly adopted policies from countries providing financial aids.

It is obvious that leadership activities in Africa are largely in direct contrast to how things should be done if the continent must have a place in the global development space. The immediate things to do under the pressure of this leadership shortcoming is for people to look for someone or organization to blame for the problem and the other is to look to some individual in whom they will put undue faith to "lead" them out of the difficulties. The latter option has always serve as platforms for dictators to come into power because the people are desperately in need of someone to solve their problems (Heifezt, 1994) and unscrupulous politicians have used this option severally to gain access to power only to end up making life more difficult for their people and the vicious cycle of difficulties continues. This paper explore the challenges and consequences of leadership failure in Africa and the need for leadership that will promote national adaptations to domestic and international demands in the public interest in African countries and how this leadership type can be nurtured through the education system.

\section{Leadership: A Conceptual Framework}

Existing literature show that there are many definitions of leadership as there are many scholars who have made attempts to define it. According to the OECD (2001), the core of leadership is how individuals influence others, particularly in respect to accessing their inner motivation. Sometimes it refers to the possession of personal properties such as courage, stamina, or charisma. At other times, it means a property of a position which dispenses power, authority, and responsibility.

Global leadership dimensions and their meanings defined by the GLOBE study (Robert J. House, Paul J. Hanges, Mansour Javidan, Peter W. Dorfman, 2004).

Table 1: Global Leadership Dimensions (Robert J. House, Paul J. Hanges, Mansour Javidan, Peter W. Dorfman, 2004)

\begin{tabular}{|l|l|}
\hline Global Leadership Dimensions & Meanings \\
\hline Charismatic/Value Based & $\begin{array}{l}\text { Reflects the ability to inspire, to motivate, and to expect high-performance } \\
\text { outcomes from others on the basis of firmly held core values. }\end{array}$ \\
\hline Participative & $\begin{array}{l}\text { Emphasizes effective team building and implementation of a common } \\
\text { purpose of goals among team members. }\end{array}$ \\
\hline Humane Oriented & $\begin{array}{l}\text { Reflects the degree to which managers involve others in making and } \\
\text { implementing decisions. }\end{array}$ \\
\hline Autonomous & $\begin{array}{l}\text { Reflects supportive and considerate leadership but also includes compassion } \\
\text { and generosity. }\end{array}$ \\
\hline Self-protective & \begin{tabular}{l} 
Independent and individualistic leadership. \\
mecuses on ensuring the safety and security of the individual or group \\
\hline
\end{tabular} \\
\hline
\end{tabular}

Effective leadership is the desire of every society as the success or failure of the society whether in public or private settings is dependent on the presence or absence of an effective leadership. What makes an effective leadership has been the subject of many researchers and diverse theories have been postulated to describe the attributes of effective leadership. The trait theory identifies motivation, personality and ability as determinants of leadership effectiveness (Yukl, 1994; Gibson et al., 2003). According to Buhler, (1995) the ability to develop and articulate a vision, honesty, energy, commitment, integrity, internal locus of control and a passion for continuous improvement are signals of effective leadership. The transactional theorists describe effective leaders as those who maintain an equitable exchange between them and their followers by focusing on their mutual self-interests while generally keeping the organization running on a steady course without any major attempt to make radical changes. They help the followers identify what must be done in order to accomplish the desired results (Rosenbach, 2003; Gibson et al., 2003). The transformational leader inspires followers to perform more than originally expected by providing a clear mental picture of the important vision and mission. These leaders tend to be role models in their daily actions. They also empower their followers to perform beyond expectations by sharing power and authority and monitoring how they use it (Hartog et al., 


\section{7; Rosenbach, 2003).}

Leaders appeal because those who follow them believe that their values and deeper interests are served by so doing. Jordi Canals (2012), emphasized that leadership is not about charismatic qualities (though they may help or not), but about competency: the capacity to understand a problem or a challenge, identify solutions, set up coalitions and teams to work on them and implement them, while creating the right context and offering meaning to the people affected, being the citizens of a country or the employees of a company. Several scholars like Chrislip (2002) and Crosby and Bryson (2005) articulated collaborative leadership models called "facilitative" leadership pertinent to public managers.

The collaborative leadership focus on leadership as a process of pulling stakeholders together to solve public problems, thus leadership is not seen in terms of accomplishing organizational objectives, the focus is on solving public problems, which by implication means that "collaborative" leadership is exercised across all sector, and "public" leadership, in this respect, is not limited to government organizations. Collaborative leaders are often described as entrepreneurs, with open mind and are risk taking (Sullivan \& Skelcher, 2002) problem solvers (Roush, 1997) driven by the passion of identifying and testing new and diverse ways to achieve the desired outcome. The key attribute of collaborative leadership is the sense of being in relation to others, a sense of mutual connectedness to others, of being part of a whole, rather than being apart from others.

\section{Root of Leadership Problems in Africa}

In the quest to securing a place in the global development sphere, Africa has consistently faced diverse challenges within and outside. While commenting on the lack of synergy between the society and leadership in Africa towards the continent's quest for development, Ngambi (2011) submitted that the major challenge facing Africa is not the absence of leaders, but the absence of appropriate and effective leadership for Africa's diversity of people and resources. In describing the trend of leadership on the continent, Rotberg (2004) observes that 'Africa has long been saddled with poor, even malevolent, leadership: predatory kleptocrats, military-installed autocrats, economic illiterates, and puffed-up posturers'. Leaders who use power as an end in itself, rather than for the public good; they are indifferent to the progress of their citizens (although anxious to receive their adulation); they are unswayed by reason and employ poisonous social or racial ideologies; and they are hypocrites, always shifting blame for their countries' distress. After almost five decades of African independence, the continent has a paucity of good governance and an abundance of deficient leadership' to show; though with few contrasting but striking examples of effective political leadership who stand out because of their strength of character, their adherence to the principles of participatory democracy, and their ability to overcome deep-rooted challenges in recent decades (Rotberg, 2006; Rothberg, 2004). Leaders in Africa operate at parallel to the needs of the society they lead, consequently the much-needed development continuously remains elusive even when it is obvious that it is possible. Critical among the diverse factors responsible for this malaise, this paper identified political naivety of public leaders, environmental and contextual factors as well as the educational factor as responsible.

\subsection{Political Naivety}

With the gale of independence blowing across the continent, a major task before the leaders of the newly independent states of Africa was to engender internal political integration, what Ernst Haas, cited by Okafor (2006, p. 41) described as a process whereby political actors in distinct national settings are persuaded to shift their loyalties, expectations, and political activities toward a new center, whose institutions possess or demand jurisdiction over the pre-existing nation-state in a nation-building process (Okafor, 2006). However, this process was not allowed to fully develop as the legacy of tribalistic leanings, what Basil Davidson cited by Okafor (2006) called "colonial tribalism", flourishes and kept a strong hold on the political life of the diverse and multi- ethnic African countries. this colonial legacy effectively employed the divide and rule policy of playing one ethnic group against another. A force vehemently fought against by the nationalists prior to independence, but they failed to crush it they mustered enough forces of unity to defeat colonialism, but their effort "was not strong enough to end the legacy of internal division.". Political naivety was a major factor responsible for this weakness among the leaders of the new independent African countries. The same has been sustained till present day with or without the conscious knowledge of the leadership of the African countries.

The political naivety of public leaders saw several African countries enmeshed in multiple coups and counter-coups in the years following their independence, due to internal contradictions and struggles which became inevitable since the colonialists bequeathed to the independent countries a false consciousness through the distortion of their history and the glorification of the colonialists' past. The colonialists' world-view became the world-view of the former colonies by default as no public leader in the former colonies have been able to replace this colonial influence with its own ideological supremacy (Okafor, 2006). In countries where imported "participatory" democracy has been adopted, political parties have no clear-cut ideological foundation and ascension to public office becomes the lot of the highest financial bidder, which has made the struggle for public 
office a "do-or-die" affair. Also, out of political naivety on the part of public leaders, there is the practice of looking to the "developed" countries for help in handling the internal affairs of the African countries.

On the economic front, political naivety was put to play as economic restructuring programmes packaged by the institutions of the former colonial powers for the countries of Africa like the Structural Adjustment Programme (SAP), aptly described as a tool of controlling the economies of African countries by the lending countries given that the latter 'have installed their own men in commanding positions in key sectors of the economies in African countries, in central banks, in customs departments, and in ministries of finance and planning', with the implication that 'no major decision or initiative on the economy can be taken without their acquiescence at the very least' (Ahiakpor, 1993).

\title{
3.2 Environmental/Contextual Problem
}

Leadership in any form and context responds to the environment, there is a typical interface between leadership and the environment. Some scholars, like Folarin (2013), averse to seeing leadership crisis in Africa from the perspective of the misdemeanor of various political rulers on the continent but should be viewed differently from fundamental causes of the crisis which include personal capacity underdevelopment, to socio-psychological and value deficiencies as well as misunderstandings that need to be addressed if Africa will be developmentally repositioned.

The quest for development in Africa predates the colonial interruption in the affairs of the countries on the continent. Prior to the colonial misadventure on the continent, there were established social, cultural, educational, political and economic systems of varying degrees in many societies on the continent. The quest for development also informed the concerted agitation for independence from the colonial forces by nationalists. However, after attainment of independence, Africa has remained at the periphery of global development circle, and continuously occupied the unenviable position at the lowest rung of the global development ladder. The underdevelopment of Africa has been attributed to a complex path dependent set of institutions which promoted authoritarianism, sustained economic decline and reinforced poverty (Acemoglu \& Robinson, 2010); inherent weakness within Africa itself occasioned by Africa's bad leadership (Houngnikpo, 2006). The poverty in Africa has been ascribed to the deliberate choice of African leaders who have chosen poverty over development of the people. As a result of the passiveness of the citizens to hold their leaders accountable and a silent international community, the African leaders have plagued their various nations and people without restraints (Mills, 2010, 2011). Folarin (2013) identified context (environment) as one of leadership challenges in Africa. At the contextual level in the case of Africa, the historical, environmental, diseases, poverty, wars and political instability, infrastructural and general underdevelopment are the turbulent issues.

\subsection{Educational Problem}

The colonialists used education as a tool for the achievement of their intentions in the countries on the continent, which includes among others the promotion and protection of their economic interests. Studies conducted on the impacts of colonization on growth and development prospects of the colonies identified distorting educational policies, which created disincentives to human capital accumulation, combined with extraction of funds which reduced indigenous capital accumulation process and direct exploitation through taxes, tariffs and restrictions on trade and foreign investments among other distortions that hampered the growth potentials of the colonies (Bertocchi \& Canova, 2002).

However, the unstable socio-economic and political environment on the continent characterized by frequent leadership change, lack of ideology, policy reversals and weak institutional patterns that characterized the postindependence African countries pointed to leadership failure attributed to the fact that African leaders have frequently come to their position with limited experience (Issa \& David, 2014). The use of education by the colonialists as a tool was not time-limited nor was it just for economic interest, it also served them the purpose of having a perpetual hold on the governance of the colonies even after independence. Therefore, after independence, the former colonies in Africa patterned their education systems after their former colonial masters by default. A trend which continued till today in spite of the diverse reforms and reviews implemented to "localize' the education systems. The over-reliance on the education system of the former colonial masters resulted in the implementation of education systems effectively at variance to the socio-economic development of these African countries. By depending on external agencies and governments for the funding of education, Africa denied itself the much-needed capacity to intervene and change the colonially bequeathed structure and, most importantly, provide the program content for its education system (Oloruntoba \& Falola, 2017).

\section{The Effects of Leadership Failure}

\author{
4.1 Education Sector \\ "Nowhere must we hold education in dishonour, for with the noblest of men it ranks foremost among blessings. If \\ ever it leaves its proper path and can be restored to it again, to this end everyone should always labour
}


throughout life with all his powers."

Plato, Laws, 644.

Today, the educational shortcomings in Africa weaken the continent's development capacity. For example, immediately after Nigeria's independence up till the late 1970s, technical and vocational education and training (TVET) was popular to meet expected skill requirements of industrialization and ease the problem of unemployment among the young school graduates. However, sequel to the concerns raised by the World Bank's rate of returns studies that showed higher returns on investment in general education than vocational education, there was a drastic shift of interest to the funding of general basic education at the expense of funding of TVET. During the period between 1980s and 1990s, the World Bank's lending for TVET to the African region dropped sharply more than $40 \%$, compared to other parts of the world (Bennell \& Segerstrom, 1998). This affected the bank's financed education training projects and undermined much external support for TVET. From this point, the attractiveness of TVET began to wane as education provision in Nigeria and the rest of the African continent largely slanted towards the general pathway and TVET pathway is considered as option for the low achievers.

Prior to this, the emergence of TVET within the context of the industrial revolution in the West as an appendage of the philosophy of "productivism" driven by quest for efficiency and profit Anderson (2008), made TVET to be seen as platform for producing necessary human capital required by the industries. This human capital approach to TVET has long been the benchmark adopted by governments of developed nations and major international organizations like the World Bank, International Labour Organization (ILO), the International Monetary Fund (IMF). Though some scholars have submitted that this approach has changed in form and emphasis over time (King, 2009; King \& Palmer, 2008; Robertson et al., 2007; Tikly, 2004; Unterhalter, 2007), much of it is still in practice. The approach sees investment in TVET on the basis of the contributions of skills to economic growth, which might have significantly informed the early prioritization of TVET by the World Bank in assigning to TVET 40\% of the bank's first education loan to Sub-Saharan Africa up until the early 1980s (Bennell \& Segerstrom, 1998; Wilson \& Rupert, 2009), because then TVET was considered a crucial component of labour force planning (Billett, 2013). The over-reliance of the African countries on aid and lack of local independent research that could have been used to compare and contrast findings from the foreign sponsored research on a strategic education in Africa were responsible, among other leadership lapses, for the adoption of the recommendations in the report hook line and sinker with the continent suffering the consequences till now. African countries keep advocating for technology transfer from developed countries without acknowledging that technology transfer does not answer to advocacy alone. The required manpower needed to receive and implement the technology being transferred is lacking in serious degrees in most African countries today thereby making technology transfer elusive.

During the period between the early and late 90 s when Nigeria as well as other African countries embarked on series of economic reforms that cut down government spending on education, especially technical and vocational education, informed by the World Bank rate of returns on education report which portrayed TVET as unprofitable for investment in developing countries (Bennell \& Segerstrom, 1998; Psacharopoulos, 1990). The consequences of the economic reforms were not favourable to development of education, especially TVET in Nigeria and several other developing countries that toed the same line (Bennell \& Segerstrom, 1998). Interestingly, China, on the other hand, at the same period, though equally received the same damning report on unprofitability of TVET, and having bought into the recommendations, was quick to make a U-turn and got busy making provisions for the development of technical and vocational education to meet the country's desire for industrialization and transformation of the economy. The consequences of both countries actions could be seen a decade later in the rising gaps in the GDP per capital of both countries as shown below.

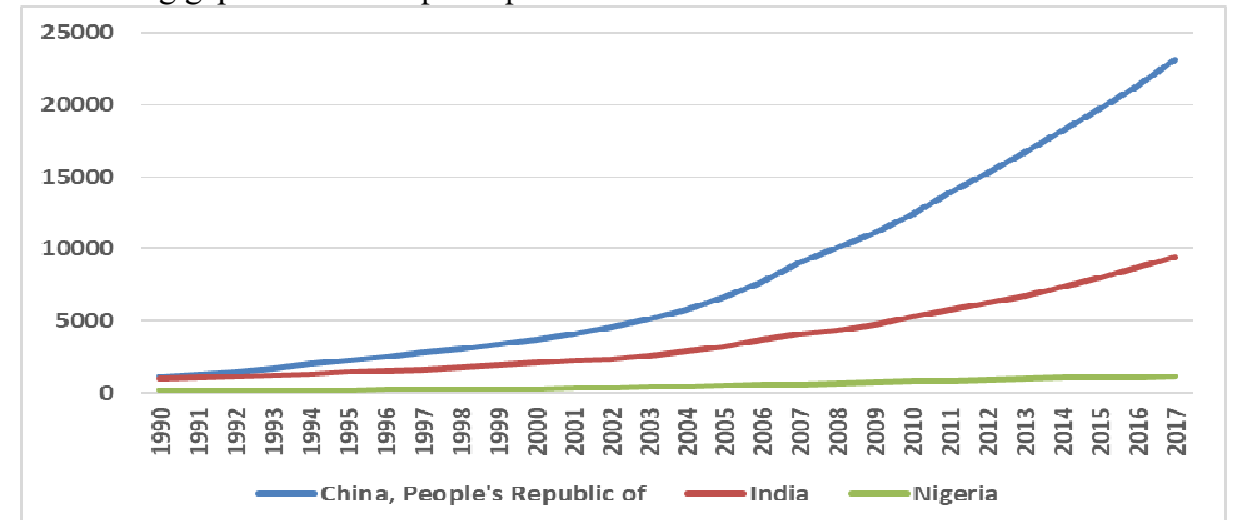

Figure 1: GDP Per Capita, Current Prices (Purchasing Power Parity; Billions of International Dollars) Source: IMF (World Economic Outlook 2017)

http://www.imf.org/external/datamapper/NGDPDPC@WEO/NGA/IND/CHN/NGA/IND/CHN?year=2018 


\subsection{Increasing Poverty}

In the midst of rising global estimates of undernourishment from 777 million in 2015 to 821 million in 2017, Africa has the highest prevalence, estimated in 2016 to be $20 \%$ of the population (FAO, IFAD, UNICEF, WFP, \& WHO, 2017). Lack of key infrastructure like roads, warehouses and irrigation systems that would help people overcome hunger contributes to the unabated poverty growth as communities are left to contend with high transport costs, lack of storage facilities and unreliable water supplies which work together to constrain farmers' yields and families' access to food (World Food Programme, 2013). Limited access to food inadvertently leads to undernourishment. The continued increase in undernourishment has been blamed, among others, on persistent instability in conflict-ridden regions, and economic slowdowns that have affected more peaceful regions and worsened the food security. Poverty is a multi-dimensional problem and major cause of undernourishment and poverty in Africa and anywhere else in the world. With $41.1 \%$ of the population of sub-Saharan Africa living on $\$ 1.90$ or less per day, hunger becomes inevitable on the continent (The World Bank, 2018). The 41.1\% of the population of sub-Saharan Africa living on $\$ 1.90$ or less per day may look like an improvement on the $42.5 \%$ of 2015 , but the marginal decrease in figure does not translate to an improvement as more people are living in poverty in Africa now than before (Beegle, Christiaensen, Dabalen, \& Gaddis, 2016). A feature of poverty is that it is often in a cycle with children who are exposed to long-term undernutrition becoming stunted, which in turn leads to long- term consequences including decreased labor productivity and income-earning potential (FAO et al., 2017). Two major factors among the various factors identified as cause of poverty in Africa are conflicts, and governance (World Hunger education Services, 2016).

Poor governance (poor public leadership) is a major hinderance to solving the poverty problem in Africa. Available research shows that investment in agriculture is more effective in reducing poverty and hunger than investment in any other sector, while good governance with good policies that allow for growth can increase food security and prevent famine (Dorosh Paul, 2017; FAO et al., 2017). however, the best the governments of countries on the continent have done is politicizing and paying lip service to investment in this critical sector capable of liberating the continent from the poverty trap. The problem of governance (public leadership) has led to the prevalence of avoidable conflicts and violence on the continent which directly impact on all levels of the food system resulting to food insecurity and hunger. Conflict often puts constraints on employment and income opportunities, exports and imports (which can lead to limited food availability and affordability), as well as affects availability of food if resources (land, equipment, etc.) used to produce food are destroyed during times of conflict. Statistics showed that in 2017, conflict was the major cause of hunger and food insecurity: a lack of secure access to sufficient amounts of safe and nutritious food for normal growth and development and an active and healthy life. Out of the 18 countries 74 million individuals affected, 11 countries were in Africa, with about 37 million people (Food Security Information Network, 2018). The young nation of South Sudan has been enmeshed in conflict since 2013, which has exacerbated increase food insecurity. More than $42 \%$ of the population faced severe food insecurity (FAO,IFAD, UNICEF, WFP, 2018). Poor governance, a reflection of poor public leadership characterized by poor policies, corruption, insensitivity to public needs is the bane behind the continued increase in poverty in Africa in view of the abundant resources the continent is endowed with.

\section{Imperative of Leadership Development Education in African Countries}

There has never been a better time to emphasize the need for African countries to embark on deliberate and focused leadership development education programme than now considering the rapidly changing dynamic environment with strong influence from information and technological advancement, globalization and constantly changing global competitiveness demands. The old wineskins cannot hold the "new wines" churned out by the variety of dynamic social and economic demands of the various countries on the continent. New approaches to leadership are required, which are better fitted for the tasks of redesigning, renovating or reinventing existing organisations, as well as securing coherence, accountability, and co-ordination among policies and various interests. There are arguments that globalization has not only widened the gap between rich and poor countries (Dutt \& Mukhopadhyay, 2009; Joyce, 2008) but has also increased the income inequality within countries (OECD, 2011).

African countries need leaders with adaptive capacity (Bennis \& Thomas, 2002) to promote the adaptation that will not only restore, but also promote the fundamental interests and values of their society when existing circumstances create contradiction between how things are being done and how they should be done (OECD, 2001). What need to be done on the African continent is confronting and overcoming the common foe of poverty and poverty-triggered insecurity.

In view of the low peripheral position of Africa in the global political, social and economic order, Gumede (2015) contended that Africa's much needed socio-economic development should be informed by the joint pursuit of thought leadership, thought liberation and critical consciousness. The dominance of foreign thoughts in the conceptualization and implementation of developmental and other policies, even with the inevitable abysmal failure of such thoughts to bring about the much-needed transformation in Africa and the 
world at large coupled with the entrapment of African leadership and citizenry by these foreign thoughts make thought liberation indispensable while the low levels of (critical) consciousness kept Africa and Africans in chains, hence the case for higher levels of critical consciousness (Gumede, 2015).

As the world is constantly adapting to the demands of globalization which require people to think and act globally (OECD, 2001), the dynamic global context requires leaders with cogent understanding of the constantly changing demands and how to meet them are in appropriate positions to make relevant decisions. Majority of the economy of the African countries are driven by informal sector which is also the major employer of labour compared to the official public service. The implication of this is the need to have the right kind of leaders with the appropriate leadership qualities at the helms of affairs in these critical sector that drives the economy of the countries. With Africa struggling at he lower rungs of global competitiveness index as well as occupying unenviable position in the Global Value Chain (GVC), the continent's quest for space in the knowledge-driven global development sphere will only be achieved when a new generation of inspirational leaders possessing and promoting knowledge as well as inspiring others to create and share knowledge occupy leading positions

How well Africa is responding to the changing global paradigms of globalization, world perspectives, technology, international speed of events and democratization is a major leadership challenge on the continent (Folarin, 2013).The constantly changing demands requires that the focus of leadership from the "authoritarian" "top-down" style traditional leadership paradigm prevalent in most African countries today give way to accommodate current demands which make it imperative for leaders to explore and adopt options beyond their authority to influence their followers as well as get the commitment instead of compliance from their followers (OECD, 2001).

As advancement in science, information and technology keeps bourgeoning, African countries will continue to remain on the periphery of global development space if the appropriate skills and competencies to meet the demands of the present day are not found in leaders in the public sector as well as in other sectors. Africa critically requires leaders who can engender national and regional integration through strategic transformational ideas in cognizance of the need of their immediate environment while focusing on delivery of results. The internal fragmentation in most countries on the continent is a major disservice to sustainable development. A factor that has been effectively exploited against the masses by unscrupulous political mercantilists. Existing statistics show that African countries trade more with the outside world than they trade with themselves, intracontinental trade which has the capacity to boost the much-needed development on the continent is pushed to the back bench as African countries continued indiscriminately to export primary commodities with no value added prior to export. The continued reliance on primary commodity export has adversely affected the continent's global competitiveness.

\section{Holistic Leadership Development Education: the Way Out}

Africa needs "Effective Education": holistic leadership development education for the young ones, one that is geared towards breaking the cycle of disadvantages while strengthening the cycle of advantages in her quest to occupy enviable global development space. Effective education will reverse the trend of the "Cycle of Disadvantages" into a "Cycle of Advantages' where the lid of disadvantages is lifted, and the citizens are able to live in a "free and egalitarian society" as a result of quality education delivery. The lack of effective education places a huge burden of limitations on the citizens, thereby limiting their ability to make meaningful contributions to the development of their immediate communities as responsible citizens. With a young population that has the potentials to build the continent's future prosperity, Africa today, has more young people in classrooms than in the past, but the challenge is that they are not learning what is required for them to thrive both now and in the future (Dangote Aliko, 2018). While calling for an educational revolution in order to realize the continent's potentials, Dangote (2018) emphasized that an entrepreneurial and knowledge revolution will provide platform for a properly educated workforce and entrepreneurial class having the skills and drive to thrive as new technologies change the nature of work, leisure, the environment, and society - and tackle the continent's most pressing challenges. 

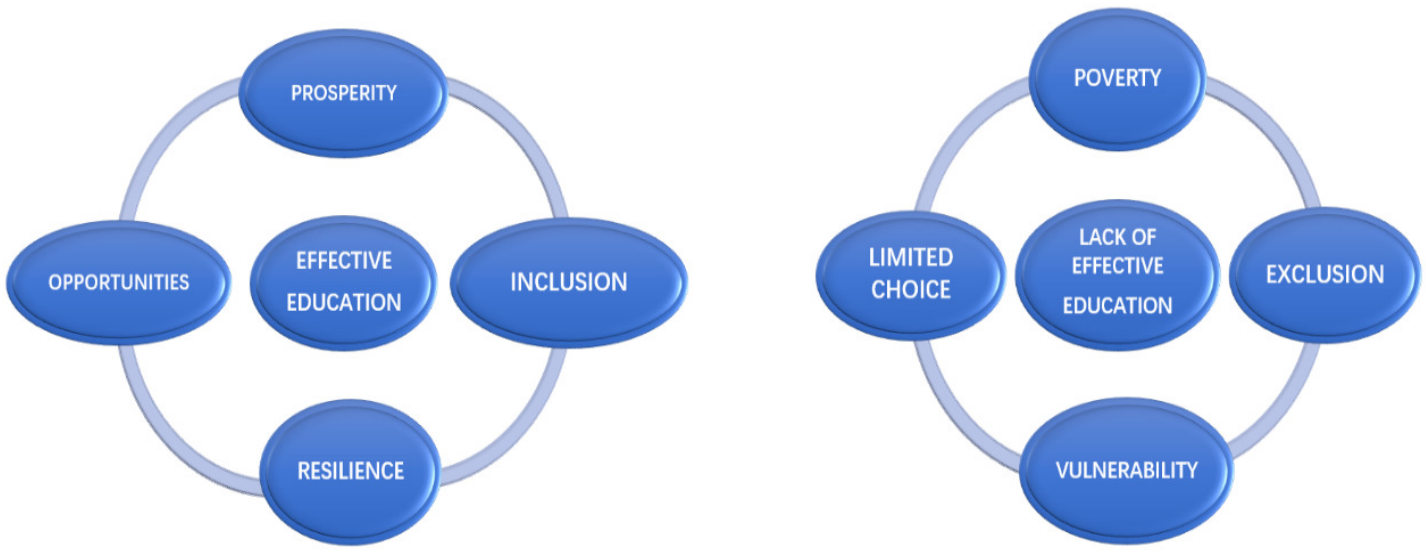

Figure 2: Impacts of Effective VS Lack of Effective Education

The education system in various countries in Africa place little or no emphasis on developing quality leadership. It can be said in other words that the education systems are not "Pro-sustainable development". Sustainable development in summary postulates that a generation meets its need without jeopardizing the opportunity of the coming generation to meet its own need. If viewed from this perspective, the education systems in Africa today cannot be described as being "sustainable". The myths surrounding the subject of leadership on who a leader is and what are the characteristics of leaders and leadership (Ekaterina Walter, 2013; Smith, 2000), have been intrinsically woven into the cultural fabrics of most countries in Africa which explains the unique difference of the leadership style on the continent. This misconception can only be corrected through a strategic, deliberate and focused leadership development education. Some of the myths about leadership are which have been empirically proven untrue are shown in the table below.

Table 2: Leadership Myths (Ekaterina Walter, 2013; Smith, 2000)

\begin{tabular}{|l|l|}
\hline Myth & Fact \\
\hline $\begin{array}{l}\text { Leadership is a unique } \\
\text { ability only given to a few. }\end{array}$ & $\begin{array}{l}\text { This is not true. While some may think that leaders are born, most are said to be } \\
\text { made through the skills and abilities they learn throughout life. And like any } \\
\text { other skills, leadership skills take time, training, and tremendous dedication. }\end{array}$ \\
\hline $\begin{array}{l}\text { Effective leadership is based } \\
\text { on control, coercion and } \\
\text { manipulation }\end{array}$ & $\begin{array}{l}\text { False. Leaders gain their followers through the use of respect and the ability to } \\
\text { inspire people to work towards a common goal. }\end{array}$ \\
\hline $\begin{array}{l}\text { Good leaders are highly } \\
\text { educated. }\end{array}$ & $\begin{array}{l}\text { Not necessarily. While education may enhance some aspect of a leader's skills, it } \\
\text { cannot make a leader on its own. This is evidenced by the success of scores of } \\
\text { not well-educated leaders in business, politics and society in general }\end{array}$ \\
\hline $\begin{array}{l}\text { Great leaders are born, not } \\
\text { made }\end{array}$ & $\begin{array}{l}\text { Leadership is a skill, not a genetic disposition. Leadership is much like other } \\
\text { forms of creativity in this regard. The person who appears to hold the best genetic } \\
\text { or socioeconomic hand doesn't necessarily win (Bennis \& Thomas, 2002). }\end{array}$ \\
\hline
\end{tabular}

Another subject of debate is whether leadership can be taught or not and the questions of what (content) and how (method) leadership should be taught. The works of researchers (Connaughton, Lawrence, \& Ruben, 2003) which showed that effective leaders are results of both inherent traits and carefully developed skills countered the long-standing thinking that leadership skills and abilities are natural endowments. Though a subject of hot debate among scholars in the field of leadership, with many disagreeing with the notion that leadership can be taught, several scholars agreed that though there are some natural endowments beneficial to leadership effectiveness, there are other important aspects of knowledge, skills and abilities that make up an effective leader that can be taught (Bennis \& Thomas, 2002; Connaughton et al., 2003).

Research has shown that there is an increasing gap between demand for and supply of qualified leaders which has become a major concern for many organizations who are constrained to engage external consultants due to unavailability of requisite leadership capabilities internally (Elmuti, Minnis, \& Abebe, 2005). The lack of qualified effective leaders has been linked to flaws in the leadership curriculum in most of the leadership training schools, which calls for a more holistic approach to leadership education, a departure from the conventional approach which focused primarily on theoretical preparation of students with rigorous theoretical training involving conceptual and analytical training (Nirenberg, 2003). The lack of holistic approach to leadership education is also coupled with lack of proper ethical education leading to proliferation of corporate scandals in recent years (Elmuti et al., 2005). The holistic leadership development education will focus on building in the learners adaptive capacity which include such critical skills as the ability to understand context and to recognize and seize opportunities (Bennis \& Thomas, 2002). 
The holistic approach involves a multi-disciplinary stream (Milter \& Stinson, 1995) that embraces global perspectives, one that combines an openness to and awareness of diversity across cultures and with a propensity and ability to synthesize across this diversity, because organizational (public or private) success in exploiting emerging opportunities and tackling accompanying challenges is largely dependent on the leadership's depth of understanding of their operating environment (Gupta \& Govindarajan, 2002).Training leaders to develop a global perspectives and agenda via leadership development education (Connaughton et al., 2003; Stinson \& Milter, 1996) will bring this into reality. Holistic approach to leadership development education connotes the integration of strong ethics education not just as an effort to satisfy minimum academic requirement, but a core subject. A strong leadership education must help instill in students the practice of authenticity, honesty and an absolute dedication to be the best possible leader (Elmuti et al., 2005).

In adopting the holistic approach, emphasis should be more on new leadership models that involves all levels of distinct roles (OECD, 2001) taking a cue from the classified leadership types of the US Government which include: strategic leadership, team leadership, and technical leadership.

- Strategic leadership is required at the higher levels for such components as strategic thinking, political savvy, vision, external awareness, influencing or negotiating, and cultural awareness.

- Team Leadership in the middle level, is more important than others, with team building and interpersonal skills as crucial competencies.

- Technical Leadership at the lower level emphasizing professional and technical skills.

The idea of leadership being required at all levels is revolutionary in its potential impact and is an important driver of the move to redefine public sector leadership (OECD, 2001).

A proposed a three-stage model of leadership education and development (Elmuti et al., 2005) is pertinent to the holistic approach and the composition is as shown in the figure below:

\begin{tabular}{rl|}
\hline Fundamental Academic Knowledge and Skills \\
- & Financial analysis \\
- & Computer skills \\
- & Writing skills \\
- & Multidisciplinary skills \\
- & Other functional skills \\
\hline
\end{tabular}

\section{STAGE 1}

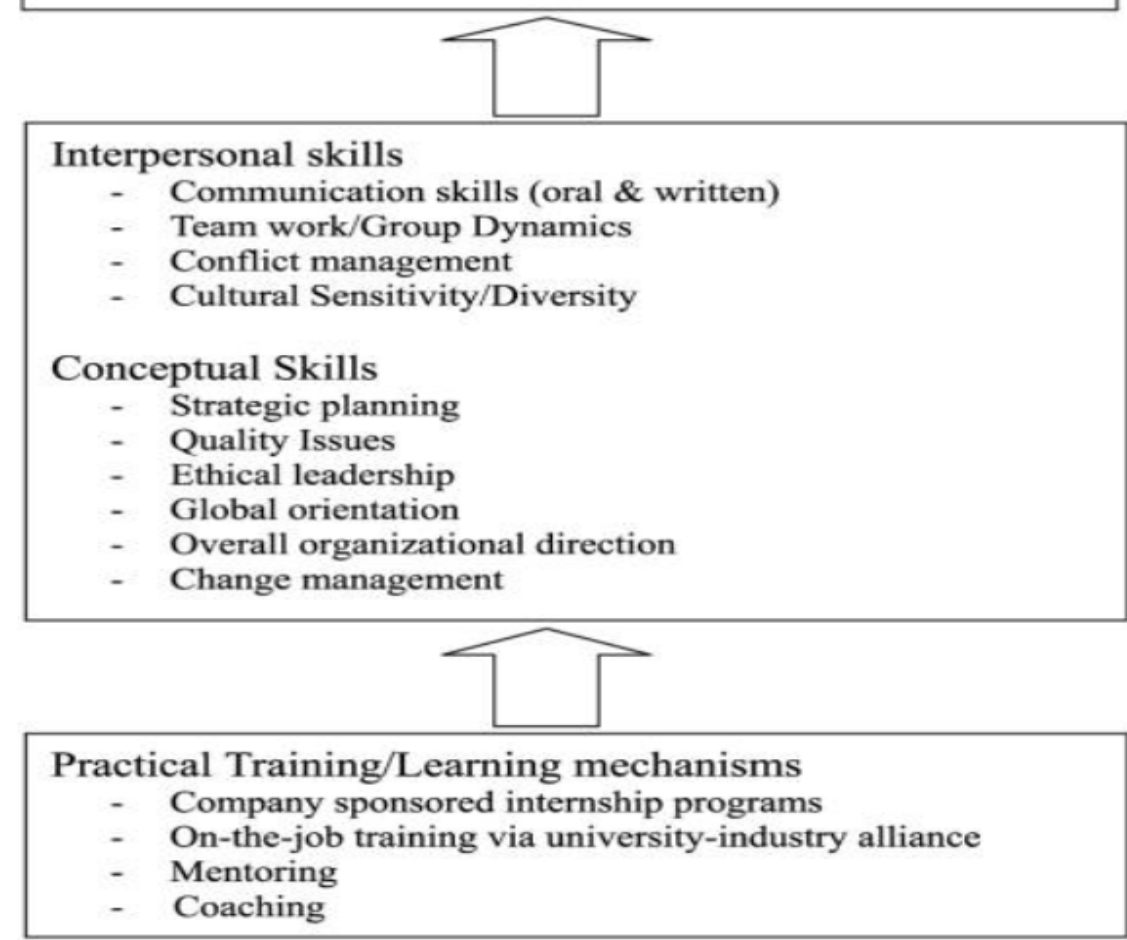

STAGE 2

Figure 3: The Multi Stage Leadership Education Model (Elmuti et al., 2005)

The first stage of the model (Stage 1) is introductory and serves as foundation for developing other more relevant leadership skills. The stage includes both the conventional "hard" skills and the multi-disciplinary skills.

The second stage (Stage 2) include the development of interpersonal and conceptual skills while it also incorporates ethical leadership, a significant part of the whole in view of the need to have a more authentic, honest and dedicated leader. 
The third stage (Stage 3) includes the development of practical skills, integrating the conceptual and theoretical knowledge with the real world application, thereby enabling the learners to practice what they have already learned in the real world environment with the necessary and constructive feedback.

\section{Summary and Conclusion}

There is a quintessential nexus between the quest for development in Africa and the quality of leadership available per time on the continent. This paper explored the concept of leadership from a broader and inclusive perspective: covering leadership in all levels of public and private sector against the background of the research evidence that leadership does not exist in vacuum, rather, it exists in response to the demands of the environment/context around it. The paper explored the causes and impacts of leadership problem in Africa and proposed the adoption of a holistic leadership development education programme with a global perspective, having the adaptive capacity to take advantage of happenings in the environment (local and international) for the sustainable development of their respective domains. This paper acknowledges the significance of natural leadership endowments but aligned with the empirical findings that leadership can be taught in addition to the natural endowment in order to enhance effective leadership. It proposes the holistic approach to leadership development education which involves a multi-disciplinary stream that embraces global perspectives, one that combines an openness to and awareness of diversity across cultures and with a propensity and ability to synthesize across this diversity without leaving out the critical requirement for ethics education in leadership development education. Leadership education should not be left in the hands of business schools alone but must be integrated into the regular education streams in view of the fact that leadership is required in every level in all sectors of a nation (public and private). This calls for the multi-disciplinary stream which will help in preparing the learners for a more dynamic, responsive and responsible future as leaders in their various endeavours in life.

\section{References}

Acemoglu, D., \& Robinson, J. A. (2010). Why Is Africa Poor? Economic History of Developing Regions, 25(1), 21-50. https://doi.org/10.1080/20780389.2010.505010

Ahiakpor, J. C. W. (1993). Challenges of Leadership in African Development edited by Olusegun Obasanjo and Hans D’Orville New York and London, Crane Russak, a member of the Taylor \&amp; Francis Group, 1990. Pp. vii + 258. $£ 44.00$. $£ 25.00$ paperback. The Journal of Modern African Studies, 31(04), 692. https://doi.org/10.1017/S0022278X00012374

Anderson, D. (2008). Productivism, Vocational and Professional Education, and the Ecological Question. Vocations and Learning, 1(2), 105-129. https://doi.org/10.1007/s12186-008-9007-0

Beegle, K., Christiaensen, L., Dabalen, A., \& Gaddis, I. (2016). Poverty in a Rising Africa. The World Bank. https://doi.org/10.1596/978-1-4648-0723-7

Bennell, P., \& Segerstrom, J. (1998). Vocational education and training in developing countries: has the World Bank got it right? International Journal of Educational Development, 18(4), 271-287. https://doi.org/10.1016/S0738-0593(98)00021-2

Bennis, W. G., \& Thomas, R. J. (2002). Geeks and Geezers: How Era, Values, and Defining Moments Shape Leaders- How Tough Times Shape Good Leaders. Boston: Harvard Business School Press.

Bertocchi, G., \& Canova, F. (2002). Did colonization matter for growth? An empirical exploration into the historical causes of Africa's underdevelopment. European Economic Review, 46(10), 1851-1871. https://doi.org/10.1016/S0014-2921(01)00195-7

Billett, S. (2013). Learning through practice: beyond informal and towards a framework for learning through practice. Revisiting global trends in TVET: Reflections on theory and practice.

C. Crosby, B., \& Bryson, J. M. (2005). (J-B US non-Franchise Leadership) Barbara C. Crosby, John M. BrysonLeadership for the common good_tackling public problems in a shared-power world-Jossey-Bass (2005).pdf.

Canals, J. (2012). Leadership development in a global world: The Role of Companies and Business Schools. https://doi.org/10.1017/CBO9781107415324.004

Chrislip, D. D. (2002). The Collaborative Leadership Fieldbook (Vol. 29). Retrieved from http://books.google.com/books?hl=en\&lr=\&id=dFzXJ7EGFGkC\&pgis=1

Connaughton, S. L., Lawrence, F. L., \& Ruben, B. D. (2003). Leadership Development as a Systematic and Multidisciplinary Enterprise. Journal of Education for Business, 79(1), 46-51. https://doi.org/10.1080/08832320309599087

Dangote Aliko. (2018). Why Africa needs an education revolution to achieve its potential. Retrieved October 3, 2018, from https://www.weforum.org/agenda/2018/10/africa-s-future-depends-on-improving-education/

Dorosh Paul. (2017). Ending famines and chronic hunger requires good governance | IFPRI. Retrieved October 7 , 2018, from http://www.ifpri.org/blog/ending-famines-and-chronic-hunger-requires-good-governance 
Dutt, A. K., \& Mukhopadhyay, K. (2009). International institutions, globalization and the inequality among nations. Progress in Development Studies, 9(4), 323-337. https://doi.org/10.1177/146499340900900406

Ekaterina Walter. (2013). 5 Myths Of Leadership. Retrieved October 9, 2018, from https://www.forbes.com/sites/ekaterinawalter/2013/10/08/5-myths-of-leadership/\#63ab2cdc314e

Elmuti, D., Minnis, W., \& Abebe, M. (2005). Does education have a role in developing leadership skills? Management Decision, 43(7/8), 1018-1031. https://doi.org/10.1108/00251740510610017

FAO,IFAD, UNICEF, WFP, W. (2018). The State of Food Security and Nutrition in the World 2018. Building Climate Resilience for Food Security and Nutrition. Rome. Retrieved from www.fao.org/publications

FAO, IFAD, UNICEF, WFP, \& WHO. (2017). The State of Food Security and Nutrition in the World 2017. Building Resilience for Peace and food security. The State of Food Security and Nutrition in the World. Rome: FAO. https://doi.org/I4646E/1/05.15

Folarin, S. (2013). Africas leadership challenges in the 21st century: A Nigerian perspective. African Journal of Political Science and International Relations, 7(1), 1-11. https://doi.org/10.5897/AJPSIR09.055

Food Security Information Network. (2018). GLOBAL REPORT ON FOOD CRISES 2018. Retrieved from https://docs.wfp.org/api/documents/WFP0000069227/download/? ga=2.169874018.31329914.1528990896-254944270.1528990896

Gumede, V. (2015). Exploring Thought Leadership, Thought Liberation and Critical Consciousness for Africa's Development. Africa Development / Afrique et Développement, 40(4), 91-111. https://doi.org/10.2307/90000045

Gupta, A. K., \& Govindarajan, V. (2002). Cultivating a global mindset. Academy of Management Executive, 16(1), 116-126. https://doi.org/10.5465/AME.2002.6640211

Heifezt, R. A. (1994). Leadership Without Easy Answers. Harvard University Press.

Houngnikpo, M. C. (2006). Africa's Elusive Quest for Development. New York: Palgrave Macmillan US. https://doi.org/10.1057/9781403977250

Issa, S., \& David, K. (2014). Leadership in Postcolonial Africa. (B. G. Jallow, Ed.), International Journal of Academic Research in Business and Social Sciences (Vol. 2). New York: Palgrave Macmillan US. https://doi.org/10.1057/9781137478122

Izugbara, C. O., Tilahun, T., \& Owii, H. (2018). Fostering political leadership for the demographic dividend in Africa: relevant cultural values. Development in Practice, 28(5), 705-713. https://doi.org/10.1080/09614524.2018.1465528

Jallow, B. G. (2014). Leadership in Postcolonial Africa. (B. G. Jallow, Ed.), Palgrave Macmillan, New York. New York: Palgrave Macmillan US. https://doi.org/10.1057/9781137478122

Joyce, J. P. (2008). Globalization and Inequality Among Nations.

King, K. (2009). Education, skills, sustainability and growth: Complex relations. International Journal of Educational Development, 29(2), 175-181.

King, K., \& Palmer, R. (2008). Skills for Work, Growth and Poverty Reduction: Challenges and Opportunities in the Global Analysis and Monitoring of Skills. British Council and UK National Commission for UNESCO, London. Downloadable at: Www. Unesco. Org. Uk/Uploads/SkillsforWorkGrowthandPovertyR EductionSept08. Pdf.

Mills, G. (2010). Why Is Africa Poor? Development Policy Briefing Paper. Retrieved from www.cato.org/pubs/dbp/dbp6.pdf

Mills, G. (2011). Why Africa is Poor and What Africans can do About it. Johannesburg: Penguin.

Milter, R. G., \& Stinson, J. E. (1995). Educating Leaders For The New Competitive Environment. In W. H. Gijselaers, D. T. Tempelaar, P. K. Keizer, J. M. Blommaert, E. M. Bernard, \& H. Kasper (Eds.), Educational Innovation in Economics and Business Administration: The Case of Problem-Based Learning (pp. 30-38). Dordrecht: Springer Netherlands. https://doi.org/10.1007/978-94-015-8545-3_4

Ngambi, H. (2011). RARE leadership: An alternative leadership approach for Africa. International Journal of African Renaissance Studies - Multi-, Inter- and Transdisciplinarity, 6(1), 6-23. https://doi.org/10.1080/18186874.2011.592387

Nirenberg, J. (2003). Toward Leadership Education That Matters. Journal of Education for Business, 79(1), 6-10. https://doi.org/10.1080/08832320309599080

OECD. (2001). Public Sector Leadership for the 21st Century. Leadership. OECD Publishing. https://doi.org/10.1787/9789264195035-en

OECD. (2011). Divided We Stand. OECD Publishing. https://doi.org/10.1787/9789264119536-en

Okafor, O. V. (2006). A Roadmap for Understanding African Politics : Leadership and Political Integration in Nigeria. NEW YORK: Routledge.

Oloruntoba, S. O., \& Falola, T. (2017). The palgrave handbook of African politics, governance and development. The Palgrave Handbook of African Politics, Governance and Development. https://doi.org/10.1057/978-1$349-95232-8$ 
Psacharopoulos, G. (1990). Why educational policies can fail: an overview of selected African experiences. World Bank Discussion Papers (Vol. 82).

Robert J. House, Paul J. Hanges, Mansour Javidan, Peter W. Dorfman, V. G. (2004). Culture, Leadership, and Organizations: The GLOBE Study of 62 Societies. SAGE Publications.

Robertson, S., Mario, N., Roger, D., Tikly, L., Hillary, D., \& Ndibelema, A. (2007). GLOBALIZATION, EDUCATION AND DEVELOPMENT: ideas, Actors and dynamics. GLOBALIZATION, EDUCATION AND DEVELOPMENT: ideas, Actors and dynamics (Vol. 58). Retrieved from www.dfid.gov.uk

Rotberg, R. I. (2006). Renewing good Leadership: Overcoming the scourges of Africa. Africa Policy Journal, 1, $1-3$.

Rothberg, R. I. (2004). Strengthening African Leadership-There Is Another Way. Foreign Aff., 83, 14.

Roush, P. E. (1997). Leadership without easy answers. The Leadership Quarterly, 8(1), 85-88. https://doi.org/10.1016/S1048-9843(97)90032-1

Smith, G. P. (2000). Are you a good leader or a bad leader. Management. Retrieved from http://www.managerwise.com/article.phtml?id=28

Stinson, J. E., \& Milter, R. G. (1996). Problem-based learning in business education: Curriculum design and implementation issues. New Directions for Teaching and Learning, 1996(68), 33-42. https://doi.org/10.1002/tl.37219966807

Sullivan, H., \& Skelcher, C. (2002). Working Across Boundaries Collaboration in Public Services. London: Macmillan Education UK. https://doi.org/10.1007/978-1-4039-4010-0

The World Bank. (2018). Poverty Headcount Ratio at $\$ 1.90$ a day (2011 PPP) (\% of Population). Retrieved October 3, 2018, from https://data.worldbank.org/indicator/SI.POV.DDAY?locations=ZG

Tikly, L. (2004). Education and the new imperialism. Comparative Education, 40(2), $173-198$. https://doi.org/10.1080/0305006042000231347

Unterhalter, E. (2007). Gender, schooling and global social justice. Psychology Press.

Watson, K. (1994). Technical and Vocational Education in Developing Countries: Western paradigms and comparative methodology. Comparative $\quad$ Education, $30(2)$, 85-97. https://doi.org/10.1080/0305006940300202

Wilson, N., \& Rupert, D. M. (2009). International Handbook of Education for the Changing World of Work. (R. Maclean \& D. Wilson, Eds.). Dordrecht: Springer Netherlands. https://doi.org/10.1007/978-1-4020-5281-1

World Food Programme. (2013). What Causes Hunger? Retrieved October 7, 2018, from https://www.wfp.org/stories/what-causes-hunger

World Hunger education Services. (2016). AFRICA HUNGER AND POVERTY FACTS. Retrieved October 7, 2018, from https:/www.worldhunger.org/africa-hunger-poverty-facts-2018/ 